\title{
Essay
}

\section{About COVID-19 in Laklãnõ Indigenous Land, Brazil}

\author{
Jefferson Virgílio \\ University of Lisbon
}

\section{Introduction}

In order to try to present the reflexes of the pandemic in the Laklãnõ Indigenous Land, it would be irresponsible not to introduce the history of violence that its inhabitants have been the target of in recent centuries. It would be naive to describe the effects of the virus without contextualizing the social structure that made possible to install it over time in the territory of Santa Catarina.

I therefore avoid describing the Laklãnõ as just one of the three hundred indigenous peoples living on Brazilian soil under an unknown threat. Countless reports of indigenous people from different places, languages and peoples flood the social networks and reach the mass media, screaming in despair, seeking help and protection, resources and information, in an attempt to deal with the pandemic.

At first, this essay seeks to recover the history of contact built between Laklãnõ indigenous people and the foreign and national fronts of territorial occupation that occurred in the southern region of Brazil. Afterwards, the most visible impacts that affect the Laklãnõ indigenous people in times of COVID-19 are revealed. Last, we explore what the situation could teach anthropology.

References are not included as they are mostly available in Portuguese. ${ }^{1}$ The purpose of this essay is to provide a synthesis of information for anthropologists who do not speak Portuguese. For those who understand the Portuguese language, a summary of the current situation is available at https://youtu.be/vaicU58IdD4. ${ }^{2} \mathrm{In}$ the live video, indigenous leaders reflect on the effects and local initiatives of the

\footnotetext{
1 In English can be recommended the book "Jungle People" by Jules Henry. The Portuguese-English edition of the book "O homem índio sobrevivente do sul" by Silvio Coelho dos Santos is also recommended.

2 In Portuguese, the recommendation is to look for any text written by Nanblá Gakran, the greatest intellectual of the Laklãnõ people.
} 
Fefferson Virgílio - About COVID-19 in Laklãnõ Indigenous Land (Brazil)

three indigenous peoples living in Santa Catarina: Guarani, Kaingang and Laklãnõ-Xokleng. The essay deals only with the latter.

\section{The Laklãnõ people}

The Laklãnõ people live in the state of Santa Catarina, in the Laklãnõ Indigenous Land, in an area of nearly fourteen thousand hectares. Less than three thousand indigenous people live in the area, including Laklãnõ survivors, descendants of Kaingang indigenous and families of the Guarani people. Originally the Laklãnõ occupied vast territories in Brazil, from the state of Rio Grande do Sul to the state of Paraná, spread over the high mountains of the region. There are records of the indigenous by Spanish Jesuits prior to the year of 1650. For centuries, fronts of territorial expansion from Europe have tried to map the region. In the 19th century, colonies settled and occupied areas of traditional use. Dom João VI even decreed a "fair war" against these indigenous people. Different groups financed by the Portuguese empire and the province of Santa Catarina persecuted and murdered Laklãnõ throughout the indigenous territory. Few indigenous families have managed to migrate to remote areas, surviving the massacres.

\section{The Laklãnõ Indigenous Land}

The continued contact of the Laklãnõ people with non-indigenous society is recent and marked by two main periods. The first, at the beginning of the 20th century during approaches made by the military. In 1912, some indigenous people established relations with employees of an agency created in 1910 by the premature Brazilian republic. After disagreements, the indigenous fled to araucaria forests. In 1914, other indigenous people, in a distant region, also established relations with employees of the same agency. The agency would be called Indian Protective Service (SPI).

The 1914 contact was made by Eduardo Hoerhann, who became the tutor responsible for all decisions involving the Laklãnõ for four decades. In the first years, the area to settle the indigenous possible was reduced, ensuring that the rest of the territory was made available for colonization. Eduardo settled about 400 indigenous people. After a few decades, 104 survivors remained. The causes of death were low resistance to illness, extreme working conditions, restrictions on the indigenous diet, and reduced access to traditional medicines. These factors were fatal to more than $70 \%$ of the population.

Pine nuts and honey are sacred foods for the Laklãnõ, but the resistant trunks of the Araucaria angustifolia have stoked the greed of non-indigenous people. The forest made of the most important tree in Laklãnõ cosmology was quickly decimated. With the felling of the araucaria the animals disappeared, including the bees. And the hearts of palms transformed into canning jars. 
Honey is an important element in the Laklãnõ diet, and also a component of the traditional drink, móg, which still depends on the stone-iron, mineral characteristic of the region. Another component is Dicksonia sellowiana, which has been explored as an ornamental plant for decades. Currently, the iron-stone deposits are all outside the indigenous land, honey is a rare material, dicksonia bellowing of extinction, and palm hearts are virtually extinct in the region.

Approximately $60 \%$ of the territory demarcated for indigenous people was invaded by descendants of the colonization fronts, notably by tree-cutting explorers, eucalyptus growers, and tobacco planters.

During the 20th century the government was often military and saw the indigenous as a problem that needed to be solved. State actions ranged from genocides to incentives for new territorial occupations, including legal protection, substitution of the native language, kidnapping of children, the exploitation of natural resources and forced settlements. The Laklãnõ people were the target of all these processes.

\section{The building of the Barragem Norte}

The second period of exposure begins in the 1960s, after Eduardo was expelled from the indigenous land when he murdered a tribal chief. In 1964 the military dictatorship arises, and among its actions a commission was created to identify problems in the SPI. The SPI was terminated and replaced by the National Indian Foundation (FUNAI).

With the failure of attempts to civilize the indigenous, and the costs of these actions, the government allowed missionaries to access indigenous lands under the pretext of guaranteeing basic health care and basic education for indigenous peoples. In exchange, Pentecostal conversion would definitively enter Laklãnõ Indigenous Land.

FUNAI, improved the SPI exploration model and promoted sales of timber extracted from indigenous lands. These lands included the entire territory demarcated by the Laklãnõ people. Throughout the process, more than $70 \%$ of the population was converted to the gospel.

The situation of the Laklãnõ people was precarious, but this did not prevent the government from building a dam inside the indigenous land. Next to Blumenau, a former German colony, the rains promoted an increase in the level of one of the local rivers. To reduce the effects of floods, the area within the indigenous land was flooded. The Barragem Norte was built, and even today it is the largest water containment dam in Brazil, with a flooded area that varies between 870 and 1200 hectares. In the flooded area there were the only village and all the fertile soil, in addition to the farms and indigenous cemeteries. There was also the extermina- 
tion of native fish to the flooded area. Hence, there was the pulverization of villages.

The necessary structure for the construction of the dam and the maintenance of workers was built within the indigenous land, such as roads and bridges, markets, bars, churches and even brothels. The indigenous land would still inherit hundreds of mixed-race children from the dam, many without identified paternity, as well as groups of indigenous competing for resources between them. The Barragem Norte is reproduced at figure 1.

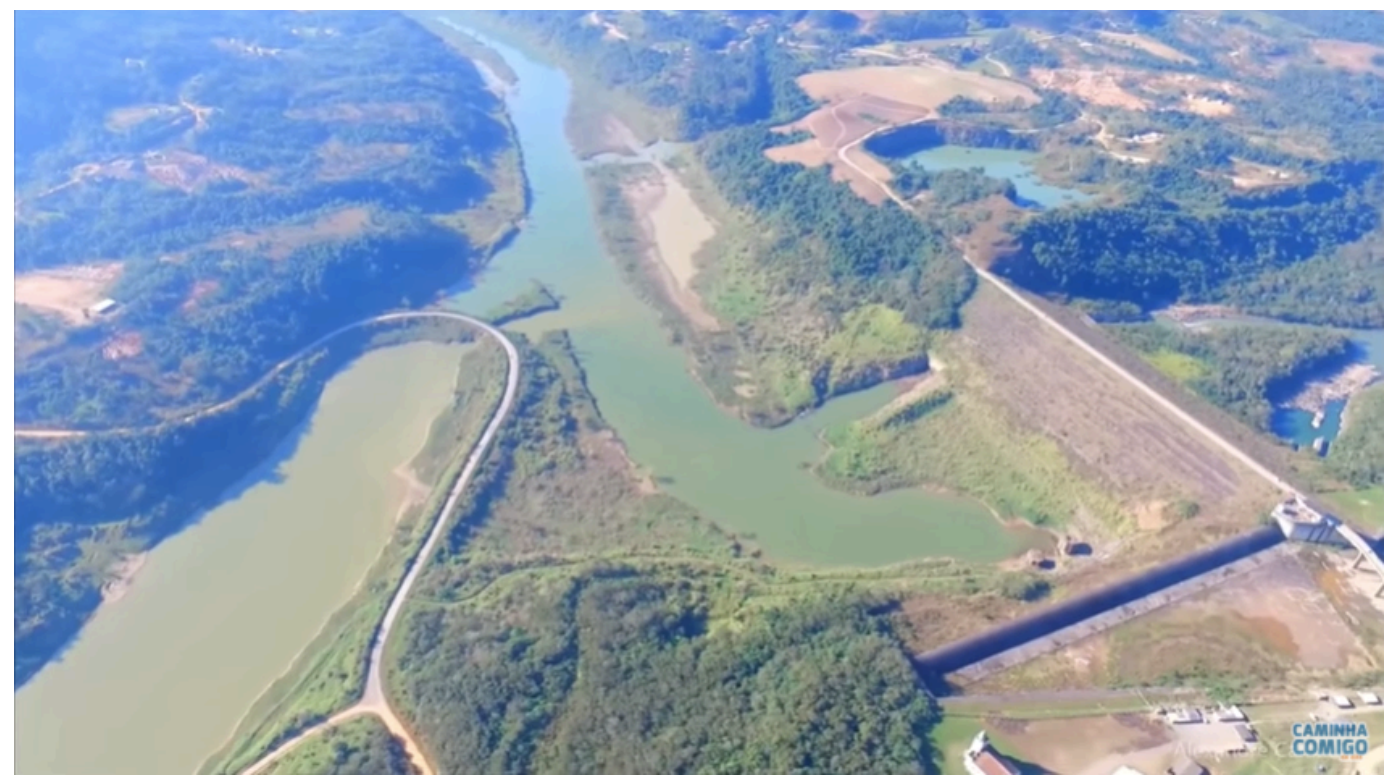

Figure 1. Aerial view of Barragem Norte. Photo by Alexandre Caminha.

\section{The end of the indigenous tutelage}

After the territorial fixation in the limited area, the indigenous have tried to live of subsistence agriculture. The economic, social and political losses after the construction of the dam have been incalculable, with the population being directed towards progressive impoverishment. Natural resources in the indigenous land were scarce, being characterized by few fertile lands and irregular relief, making the indigenous area unproductive. This set of factors created an economic dependence on neighbouring cities, encouraging migration.

In 1988, Brazil proclaimed a new constitution and eliminated indigenous tutelage. When political and legal autonomy emerged, the indigenous people were subjected to the laws of the State they were unaware of, with economic and civil dependencies on external groups, aggravated by the invisibility of the processes of cultural eradication, in addition to the population and territorial emptying. 
In the last decades, the indigenous people tried to adapt to the model of society that was established in the territory. They sought to prevent elders from dying from medical negligence, children from growing up malnourished and uneducated, and natural resources from being indiscriminately exploited. They understood that it was necessary to use the weapons of non-indigenous people. Some indigenous people started to abandon their homes to live in slums in cities far from the villages, other indigenous were exploited in tobacco plantations, which receive many types of poisons, reaching the only river that supplies indigenous land.

The indigenous exodus expands with a wave of young people, who, inspired by university quotas, abandon their homes to study. The success of these students is residual and is inversely proportional to the economic, cultural and social impact for families.

\section{The arrival of a new enemy: The pandemic}

On July 31 st, the first Laklãnõ victim of COVID-19 died. On the same day, two other infected indigenous people were confirmed, while dozens of indigenous people awaited the results of the tests. Within a few hours, the virus that was absent in the area reached one third of the villages. A few days later the first child would die. These are the only recognized deaths.

It is not a matter of quantifying fatalities and we must not summarize it in the pandemic context. The construction of the scenario that allowed the insertion of the virus in the indigenous territory began months ago, accumulating errors and neglect by various institutions and authorities, both in the state of Santa Catarina and in the rest of the country. The mistakes would happen far away, but it was only a matter of time before the effects arrived.

On February $26^{\text {th }}$, the first infected with COVID-19 in Brazil was confirmed. Subsequently, when analysing sewers, they would confirm that the virus had been in Santa Catarina since November 2019. Only on March 20th would the government issue a provisional measure making it difficult for foreigners to enter the country.

The decision was made because on March 17th the country's first death was confirmed. On March 12 ${ }^{\text {th }}$, the first infected ones in Santa Catarina are confirmed. And on March 16 $6^{\text {th }}$, the Federal University of Santa Catarina (UFSC), the largest university in the state, would suspend all classes for thirty days. It was also on March $17^{\text {th }}$ that FUNAI suspended the entry into indigenous lands. Santa Catarina would declare an emergency state on the same day.

The suspension of UFSC's activities reached sixty thousand people. Among them there were one hundred and fifty indigenous students. Even after the suspension of activities, the indigenous people remained in the capital waiting for classes to return. The refusal to return to the activities would be disclosed by the rectory 


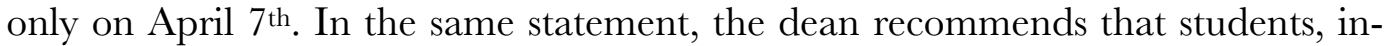
cluding indigenous people, return to their homes. Concerns about any possibly infected students would never arise.

There was no action to guarantee the students' return home. Each student would be responsible for their displacement. In August, there were still thirty indigenous students residing at the university campus, because they were unable to return home or to eat. The Laklãnõ Indigenous Territory is three hundred kilometres away from the university.

Between March and April, tests were scarce throughout Brazil. Similar to the rest of the country, Santa Catarina selected who would be tested. The priority was for those who were in direct contact with sources of infection. The possibility of asymptomatic people transmitting the virus was theoretical. They also discussed how long the virus would remain in the body. Knowledge about contagion and symptoms was meagre.

\section{The consequences of the pandemic for the Laklãnõ In- digenous Land}

For months, government information was non-existent. The terms "pandemic" and "COVID-19" appeared on television seeking to correct government and society errors. The population believed they were safe. Between April and May, Santa Catarina, and the Brazilian governments oscillated between the creation of restrictive rules to reduce contamination and the flexibility of the same rules.

It was in April that the federal government announced a monthly aid for people unable to maintain their income due to the pandemic. A financial transfer to the country's most vulnerable strata. In the process it was considered that the poorest layer of the country would have: 1) Cell phone, 2) Mobile Internet, 3) Domain over internet banking. In the end of August, there were still millions of Brazilians who had not received any of the promised instalments.

The uncertainties between restrictions and flexibilities led the indigenous people to consider imposing sanitary barriers at the access points to indigenous land. Due to doubts that arose, the Laklãnõ discussed the matter between April $3^{\text {rd }}$ and May $20^{\text {th }}$. Figures 2 and 3 reproduces two types of sanitary barriers. 


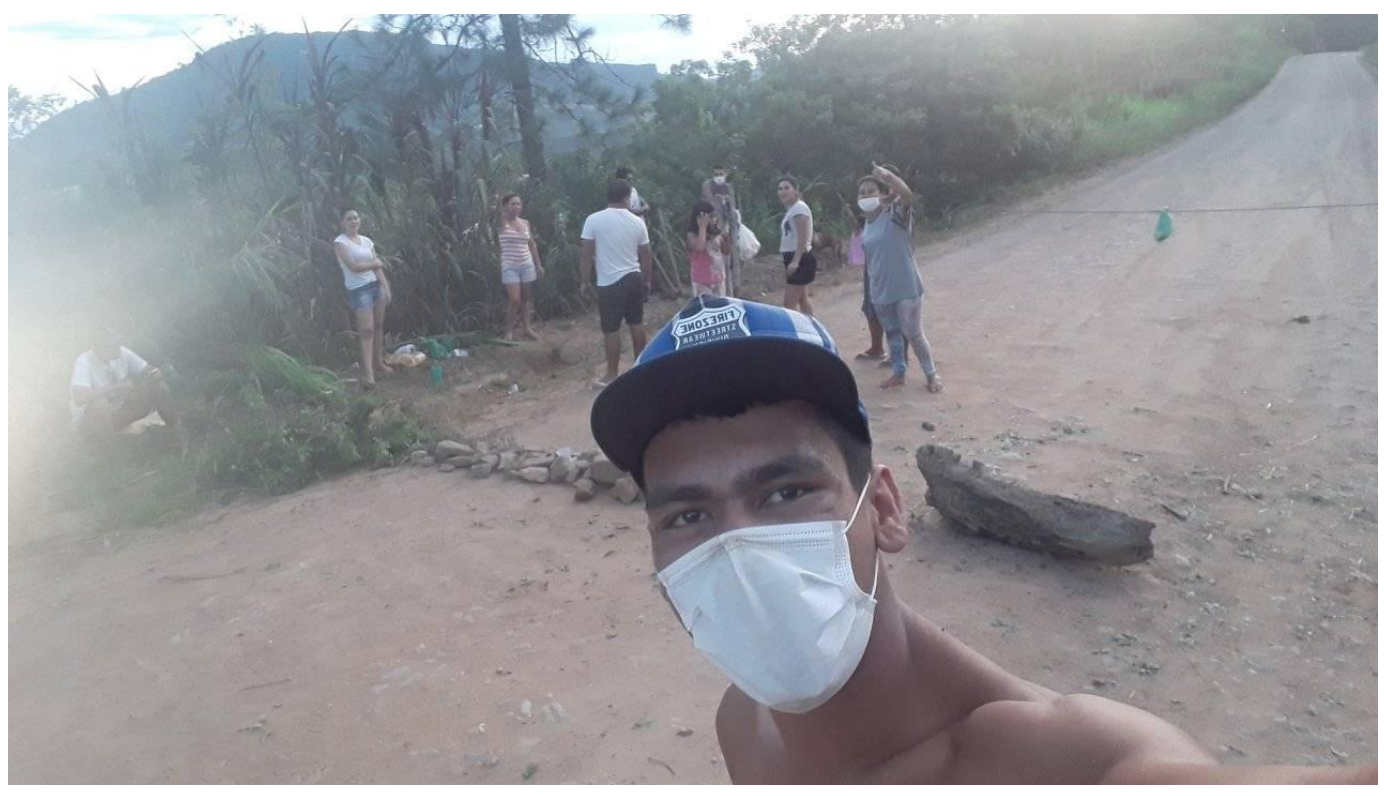

Figure 2. Sanitary barrier in the entrance of Bugio Village. Photo by Camlem Farias.

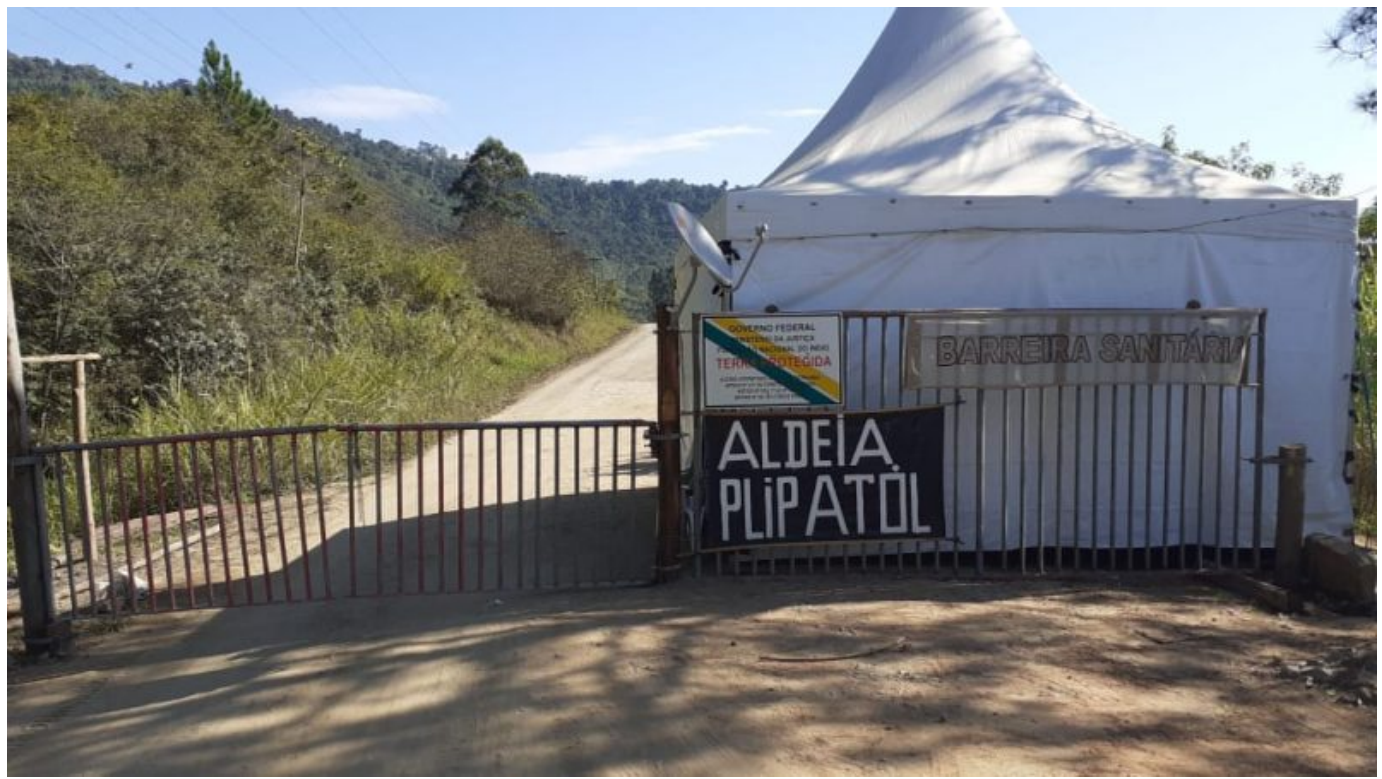

Figure 3. Sanitary barrier in the entrance of Plipatól Village. Photo by Ana Roberta Patté.

The day after the first blockade, the city council of the neighbouring city questioned whether the indigenous could impose such barriers, while they proposed to remove the sanitary barriers judicially. The responsible councillor was concerned about the impossibility of continuing to cut down trees in indigenous territory during the pandemic. 
With the introduction of barriers to access indigenous land, the indigenous have become isolated from cities on which they have become economically dependent. The few indigenous who managed to register for emergency aid had to choose between leaving Laklãnõ Indigenous Land to receive the money and not entering again or keeping the money unused in a useless digital account.

In June, winter resulted in negative temperatures in the region. Annually there is a lack of clothes and food for the indigenous people, and donations are common to reduce the impact of winter in the indigenous mountains. Due to sanitary barriers, donations did not enter the Laklãnõ Indigenous Land.

Neither donations, medical care nor emergency aid from the government could reach the indigenous territory. Those who work in the tobacco and eucalyptus plantations have had to choose between working or staying within the Laklãnõ Indigenous Land. Students arriving from other cities were isolated for seven days before entering the village. The indigenous did not know that the virus remained in the body twice as long.

On TV, the information circulated that to prevent the virus, in addition to social isolation, the use of facial masks and hand sanitizers are necessary. Social isolation arrived months later on indigenous territory. Hand sanitizer was unknown and could only be found in neighbouring cities, into which they cannot enter. Masks are a non-existent ornament and need to be purchased or produced. All the material is in neighbouring cities.

Until August FUNAI in Santa Catarina was not concerned with the seventeen thousand indigenous who live in the state. No preventive material was sent or delivered. Neither masks, nor hand sanitizer nor cleaning materials. And of course, there have been no information or tests. In addition to FUNAI, another body should have acted, but chose to remain inert: The Special Secretariat for Indigenous Health (SESAI), linked to the Ministry of Health. A ministry that since the beginning of the pandemic, remains without an effective minister.

The two previous effective ministers were dismissed after recommending social isolation, at different levels, for the entire country. The president of the republic repeatedly said that the pandemic was hysteria, and that social isolation would make the economy unfeasible.

\section{Facing the invisible enemy}

Among absent public efforts, the indigenous tried to articulate themselves. Tribal chiefs, elders and teachers began to discuss how to resolve the issue of indigenous people who needed transit between the indigenous land and neighbouring cities. It was decided upon social isolation, complemented by sanitary barriers. The prob- 
lems were the extended families and the social proximity that is very strong, especially among the elders.

Between the end of July and the beginning of August, the amount of infected multiplied, from isolated cases reaching entire families in a matter of days. In midAugust, 170 indigenous people were infected and another 150 were awaiting results. Only one out of ten villages had no confirmed infected.

So far it has not been possible to map whether the first infected arrived from UFSC, from cities neighbouring the indigenous land, or with non-indigenous pastors who insisted on entering the territory, breaking through sanitary barriers, to preach for divine intervention. Given the limited size of the temples, the social proximity during the services, the verbalization of prayers and the complete lack of personal protection material, and the neglect encouraged by the State, infection spread among the Pentecostal community.

\section{benfeitoria}

\section{[SC]Povo Indígena Xokleng contra o Covid}

O povo Indigena Xokleng grita socorro e conta com sua ajuda na luta contra o Covid-19 e nosso objetivo é diminuir seu impacto na Terra Indígena Laklãnõ.

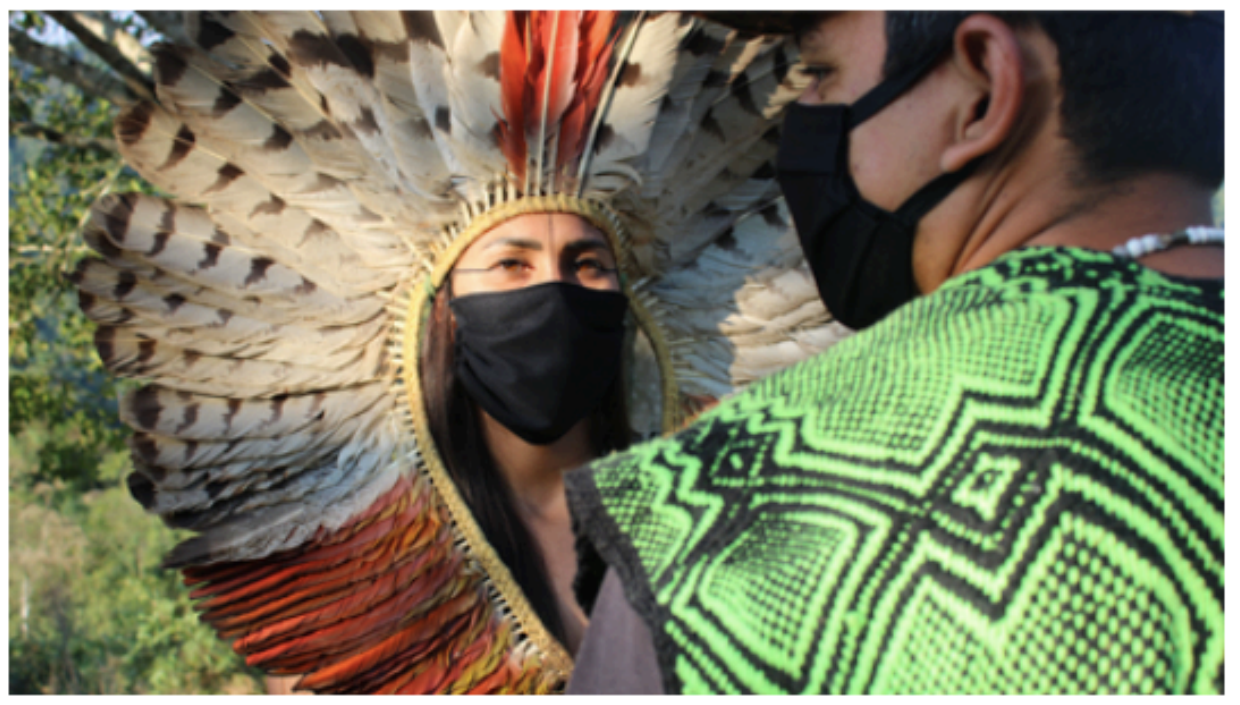

Figure 4. Print screen of the campaign to produce face masks by crowdfunding. Original photo by Fernando Almeida. 
Laklãnõ cultural collections were lost when elders died during the month of $\mathrm{Au}$ gust, due to other causes that COVID-19, but coincided with the arrival of the pandemic and the social and cultural changes it sparked.

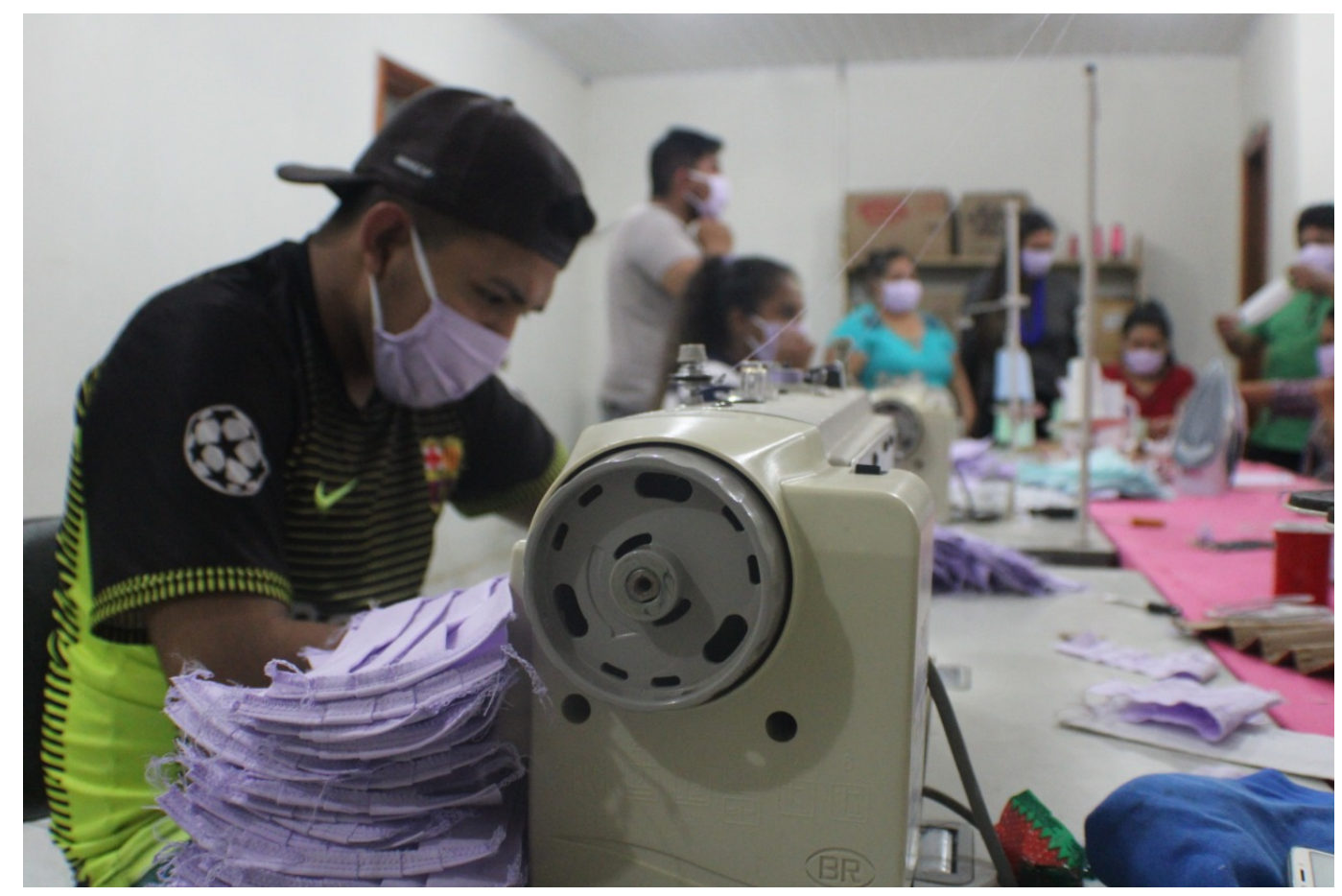

Figure 5. Face masks sewing factory. Photo by Isabel Gakran.

The peak of viral transmission coincided with the receipt of resources in an indigenous project to manufacture homemade masks for one of the villages. Precisely the last village to present infected cases. This project made it possible to renovate and expand a sewing workshop, where three thousand masks were produced and distributed across three villages. Afterwards, more initiatives produced another three thousand masks that reached more indigenous people. Figure 4 shows the online crowdfunding campaign. Figure 5 shows one of the face masks sewing factory.

With social isolation being reinforced, uninfected individuals ended up being assigned to give attention and care reserved to the elders and not just isolate them. The efforts that have been made have managed to stabilize the contagion. The numbers of infected people since then are stable and with a real possibility of decreasing. There were no new fatalities due to COVID-19. 


\section{Municipal, state and federal responses}

The four cities surrounding the indigenous territory dodged the responsibility for monitoring the indigenous who could be infected. They did not even include indigenous people in their official accounts. Other material, human and financial efforts came only after much indigenous insistence, which bordered on begging. In one of the municipalities, the indigenous people make up $70 \%$ of the population. Municipal elections will be held in November.

The governor and the deputy governor of Santa Catarina were worried throughout the pandemic about their impeachment, for they have been responsible, over months for the exorbitant amount of 33 million Brazilian reais (approx. 5 mil. EUR) being diverted in a scheme to buy overpriced ventilators. ${ }^{3}$ The few thousand indigenous who reside in Santa Catarina were not exactly a priority. Field hospitals for COVID-19 were announced, but never completed. Millions of Brazilians reais invested in them until the building of the hospitals was cancelled.

The lack of action drew the attention of the Brazilian army, legally responsible for the indigenous in Brazil until the end of the tutelage carried out in the 1988 constitution - and which preserves marks of this relationship until today - which decided to send a truck with dozens of mattresses to the indigenous to carry out the isolation of those infected. In addition to the mattresses being dirty, old and torn, the government's suggestion was to isolate these people in the indigenous school buildings. The mattresses can be seen in the figure 6 .

The situation of the schools reserved for the isolation of the infected is concluded with the State pressing for the return of the classes through distance learning. The recommendation was to use the internet and computers. The problems are the precarious electrical structures, the lack of a cell phone network in more than $80 \%$ of the area of the indigenous land and the number of computers, which throughout the indigenous land remains in two digits.

The indigenous leaders and teachers, together with the managers of the two schools, decided to make handwritten home assignments available to students every fortnight, to be done with the help of their parents. The initiative aimed at not losing the school year, a situation that is especially critical for secondary school students who would claim access to higher education. Parallel to this situation, the state education department was pressuring indigenous teachers to stay at least three days a week working at the school, in order to remain entitled to low wages. Let us not forget that schools remain a place for isolating those infected with COVID-19.

\footnotetext{
3 https://brazilian.report/coronavirus-brazil-live-blog/2020/05/13/corruption-arises-as-brazilian-statesrush-to-buy-equipment/
} 
Finally, overwhelmed by the infinite failings of the federal government, the Federal Public Ministry and the State Public Ministry, which acted similarly at the state level, remained for months unable to analyse the indigenous issues during the pandemic.

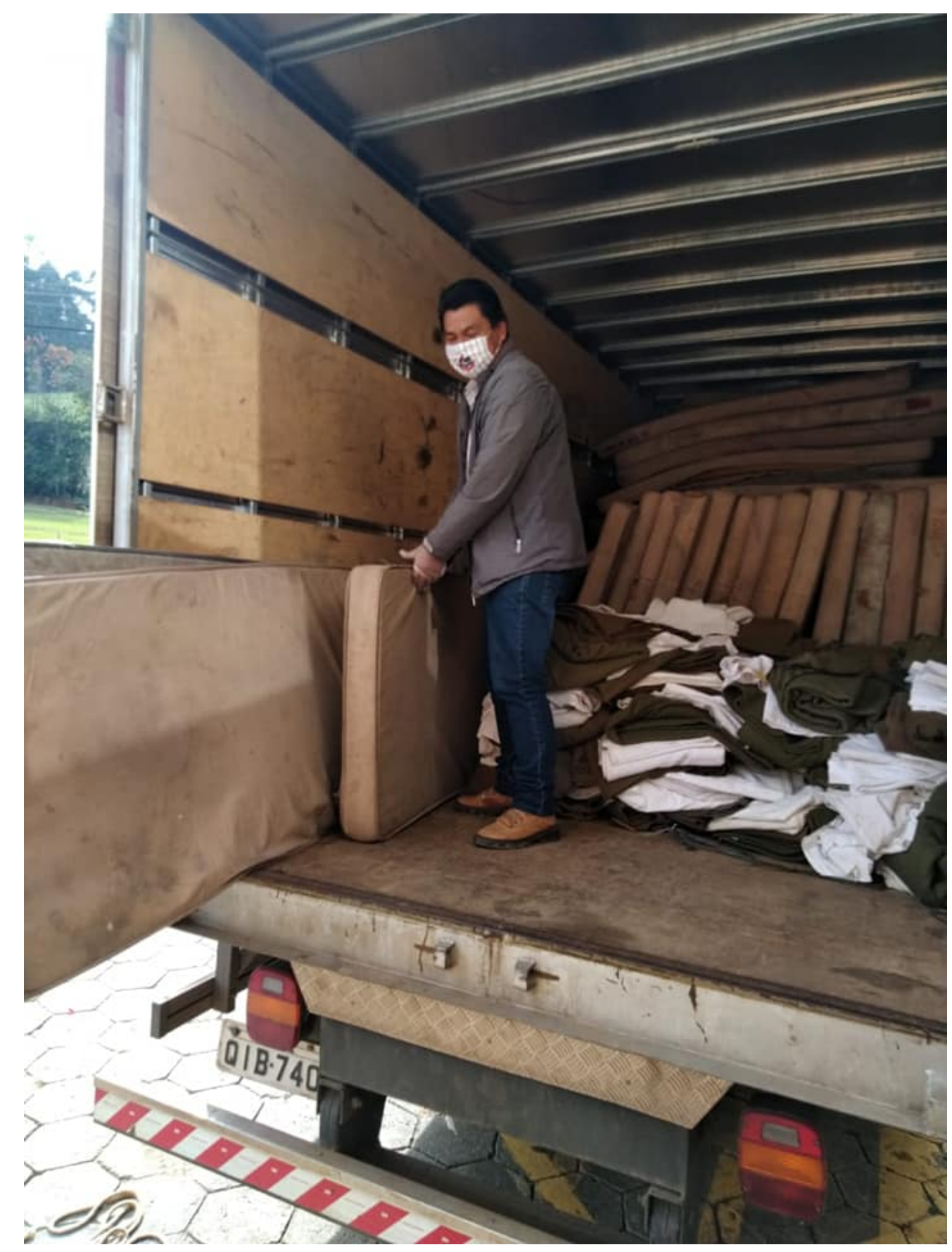

Figure 6. Delivering of dirty mattresses for the indigenous people. Photo by Nanblá Gakran. 


\section{Pandemic as a magnifying glass}

First, I would like to suggest that the pandemic can be understood as an efficient magnifying glass, capable of dramatically amplifying a whole series of characteristics of a given social structure. The immense social inequalities that have been accumulating over the last hundred years are evident, in addition to the whole series of impacts derived from the violence and exploitation to which the indigenous people have been subjected throughout the history of contact with non-indigenous society.

The examples are innumerable, from the governmental neglect, the inertia of real and critical action by researchers specialized in the subject, to the enormous dependence on the society and the surrounding economy that were established in its surroundings - adding to the vulnerabilities in the spheres of health and education, and memory and traditional culture. 